\title{
Factors in Organisational Environmental Management System Implementation - Developed vs. Developing Country Contexts
}

\author{
Constance Kola-Lawal ${ }^{* 1}$, Mike Wood ${ }^{1}$, Babajide Alo ${ }^{2}$, Andrew Clark ${ }^{1}$ \\ ${ }^{1}$ School of Environment and Life Sciences, University of Salford, Greater Manchester, England, \\ ${ }^{2}$ Department of Chemistry, University of Lagos, Akoka, Lagos, Nigeria \\ email: C.O.Kola-Lawal@edu.salford.ac.uk
}

Cite as: Kola-Lawal, C., Wood, M., Alo, B., Clark, A., Factors in Organisational Environmental Management System Implementation - Developed vs. Developing Country Contexts, J. sustain. dev. energy water environ. syst., 2(4), pp 408-421, 2014, DOI: http://dx.doi.org/10.13044/j.sdewes.2014.02.0032

\begin{abstract}
Country specificities and national cultures influence Environmental Management Systems (EMS) implementation and pro-environmental behaviour in organisations. Previous studies have focused on organisations in developed or emerging economies, creating a need to establish the extent to which findings are applicable to developing counterparts. This paper presents EMS implementation from a developing country perspective, reporting on EMS implementation factors (drivers, benefits, barriers) affecting Nigerian organisations' pro-environmental behaviour, by analysing questionnaire responses from 136 Nigerian organisational respondents. Most commonly cited drivers were 'environmental concern' and 'desire for improved organisational efficiency'. Key barriers were 'cost of implementation/budget barriers' and 'regulatory agency bureaucracy'. Key benefits were 'reduced environmental accidents and improved site safety', 'enhanced corporate image' and 'more efficient resource use'. To situate findings within a global construct, results were compared with previous studies in more developed economies. EMS implementation factors differed from those in more developed economies. Plausible explanations for differences are discussed.
\end{abstract}

\section{KEYWORDS}

Benefits, Drivers, Environmental management system, Environmental behaviour.

\section{INTRODUCTION}

The drivers, uptake, benefits and barriers of EMS implementation across organisations in a range of industry sectors and world regions have been reported in various studies [1-9]. According to these studies, the motivations for an organisation's pursuit of an EMS (or its pro-environmental behaviour), and the benefits it expects from such actions are inextricably linked [3]. However, the majority of these studies are either focused on or carried out in organisations based in developed or emerging economies, thereby restricting the widespread relevance of findings [10]. Even within the current range of studies, country-specific differences in EMS implementation have been identified [11], and linked to factors such as national cultures and country-specific contexts $[12,13,5]$. Therefore, the extent to which findings from previous studies are applicable to developing countries which may have very different cultural and socio-political contexts, should be investigated. This paper aims to identify factors (drivers, benefits and barriers) relating to EMS implementation and other forms of pro-environmental behaviour in Nigerian organisations, and to analyse and categorize

\footnotetext{
* Corresponding author
} 
identified EMS implementation factors using a specifically-developed model [13]. The study presents and analyses data obtained from 136 organisations operating in various Nigerian industry sectors.

\section{BACKGROUND}

\section{Regional influence on EMS adoption/pro-environmental behaviour}

Though adoption of EMSs (and pro-environmental behaviour) is generally increasing in developed, economically vibrant parts of the world, it is receiving nominal attention in other far less developed parts [1,3]. Despite the fact that international EMS standards (such as ISO 14001) have been adopted by geographically diverse organisations, their implementation and extent of diffusion differs in different countries [2], and it seems that uptake of these standards has been very much country/region dependent. Figure 1 summarizes the international distribution of ISO 14001 certifications in 2010, with Europe and the Far East together accounting for approximately $90.9 \%$ of certifications, and Africa/West Asia and Central/South America together accounting for only $6 \%$ of certifications.

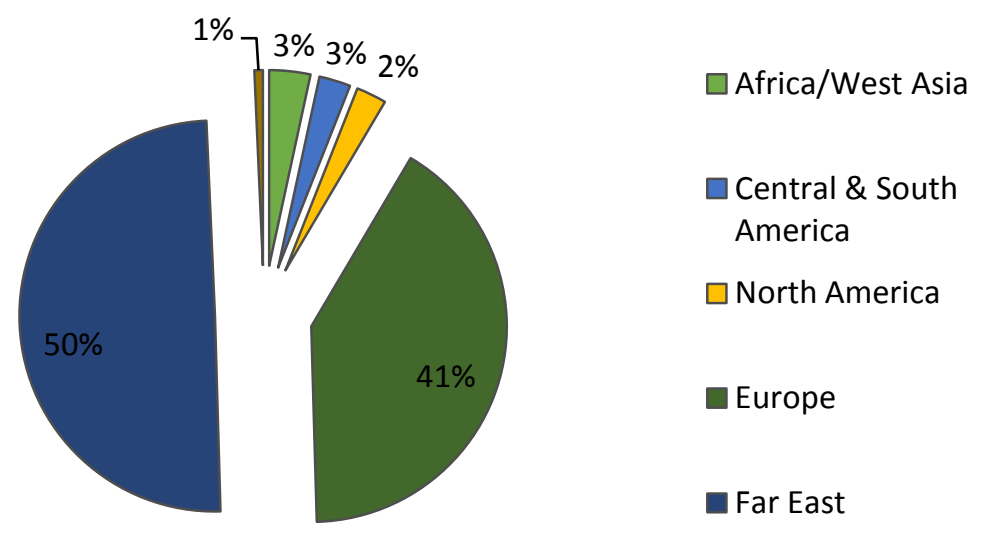

Figure 1. World share of ISO 14001 certifications in \% (Adapted from: [14])

\section{Overview of EMS implementation factors - drivers, benefits and barriers}

In determining pro-environmental behaviour like EMS implementation, organisations are often motivated by factors stemming from within, such as internal resources and capabilities [12]. Some of the most influential drivers of environmental change today include corporate awareness of the finiteness of natural resources and the need for maintaining a sense of stewardship and responsibility towards environmental issues [15], both considered to be strong internal drivers. Organisations are also increasingly influenced by external factors that compel them to play more active roles in environmental management. Market opportunities, government and regulatory influences, and institutional and community pressures all have an influence on the way an organisation manages its impact on the environment, especially in more developed societies [7, 8, 16]. Firms which experience little external pressure from outside institutions have little:

- Regulatory and compliance benefits, which organisations derive through awareness of their environmental legal and statutory requirements thereby attempting to operate within those requirements [8]; 
- Human resource benefits, where employees are positively affected when they genuinely believe an organisation is adopting pro-environmental behaviour for what is considered to be the 'right' reasons [16];

- Positive economic impacts, whereby ems implementation is likely to lead to source and pollution reductions, process intensification and improvement, improved waste management and improved productivity, all of which typically result in cost reductions and subsequently, cost savings [1, 20];

- Market access benefits, where ems implementation has the ability to provide organisations with access to new and existing markets $[1,20]$;

- Positive impact on external corporate image, where ems implementation becomes a corporate public statement and affords the opportunity of communicating to external parties - customers, suppliers, regulatory bodies, investors and the general public [20];

- The opportunity to improve environmental performance and efficiency by creating support for the implementation of other environmental practices [21-23].

EMS barriers usually arise from the cost of pro-environmental initiatives. For example, there are direct and indirect financial implications associated with EMS implementation [24], including time and human resource costs and the costs of engaging external consultants. In addition, externally certified EMSs like ISO 14001 have been widely criticized for not being sufficiently linked to environmental performance. This may be because EMS standards like ISO 14001 mainly focus on management interventions required to implement a functional EMS, and do not have inherent performance indicators or measurement metrics. As such, they cannot be referred to as performance standards but rather management standards $[1,2,8]$. Such criticisms may constitute a barrier to EMS adoption.

\section{Environmental regulation and legislation in Nigeria}

As early as the 1950's the Nigerian government developed environmental laws, a number of which are geared towards controlling environmental issues in industry. Nigeria's environmental management control efforts (acts, decrees, laws, bye-laws, edicts, regulations, policies, ratification of regional and international agreements, protocols and conventions) can be classified into:

- Special initiatives and actions (International and regional);

- Policy and institutional tools;

- Legal/regulatory tools.

These environmental management control efforts are implemented on two different levels of jurisdictional authority:

- Federal - Federal environmental provisions have jurisdiction over the entire country;

- State - Environmental provisions applicable within each of the 36 states and capital city in Nigeria.

The country has also ratified several environmental management international treaties, not limited to the following [25]:

- The United Nations Conference on Human Environment (the Stockholm Declaration), 1972;

- The Vancouver Conference on Human Settlements, 1976;

- The Vienna Convention on Protection of the Ozone Layer, 1985;

- The Lugano Convention for Civil Liabilities resulting from activities dangerous to the Environment, 1993; 
- The Istanbul Conference on Human Settlements, 1996;

- The Basel Convention for the Control of Transboundary Movement of Hazardous Wastes and their Disposal, 1992;

- The Kyoto Protocol (United Nations Framework Convention on Climate Change), 1997;

- The Rio de Janeiro United Nations Conference on Environment and Development (the Earth Summit), 1992. This led to the production of 5 documents:

○ The Rio Declaration - Principles of a healthy environment and equitable development;

- The Agenda 21 - an action plan for sustainable development in the 21 st century;

○ The Convention on Biodiversity;

- The Convention on Climate Change;

- A statement of Forest Principles.

- Rio 20+ - The United Nations Conference on Sustainable Development, 2012.

However, the Nigerian government faces the problem of implementation and enforcement of new and existing environmental laws, which must be addressed for existing legislation to be effective.

\section{The link between EMS implementation factors}

According to [3], EMS drivers and benefits are inextricably linked. This is also true of the relationship between EMS drivers and barriers, as an EMS implementation factor which drives an organisation to display pro-environmental behaviour may also bar another from implementing the same. Table 1 shows how EMS factors may serve multiple functions as drivers, benefits and barriers to EMS implementation in organisations. For instance, regulatory/legal demands/pressures can serve as a powerful driver of pro-environmental behaviour [26-28]. This EMS driver can motivate organisations to adopt EMSs in an attempt to seek compliance with regulatory standards or pressure from regulatory bodies. Simultaneously, regulatory/legal demand/pressures can also act as barriers to EMS implementation [7], preventing organisations from exhibiting pro-environmental behaviour in an attempt to avoid unwanted regulators' attention.

Table 1. Relationship between EMS implementation factors

\begin{tabular}{cccc}
\hline EMS implementation factor & EMS driver & EMS benefit & EMS barrier \\
\hline Regulatory/legal & $\sqrt{ }$ & $\sqrt{ }$ & $\sqrt{ }$ \\
demands/pressure & $\sqrt{ }$ & $\sqrt{ }$ & $\sqrt{ }$ \\
Market advantages & $\sqrt{ }$ & $\sqrt{ }$ & \\
Customer/client requirements & $\sqrt{ }$ & $\sqrt{ }$ & \\
Opportunity for new approach in & $\sqrt{ }$ & & $\sqrt{ }$ \\
environmental management & $\sqrt{ }$ & & \\
Employee relations & Resources (Human, economic, & $\sqrt{ }$ &
\end{tabular}

\section{Harmonization of EMS factor categorization models}

Though similarities exist between models for categorizing EMS implementation factors, there is little direct correlation between sets of models as a whole, especially in 
regard to functional interpretations and terminologies used. As a result of the differences in results of EMS studies conducted in different world regions, there are also marked differences between categorization models [5, 11, 12], restricting the international applicability of these models [10]. Harmonizing and re-grouping existing EMS models will provide a model with a wider applicability and cross-regional relevance, and will bridge the gaps of previous individual models, providing a consolidated model which can be used to classify EMS drivers, benefits and barriers across a range of geographical and industry settings [11]. Such a classification model has been postulated [13] and is shown in Figure 2.

\begin{tabular}{|c|c|}
\hline $\begin{array}{l}\text { Internal Neoclassical } \\
\text { Efficient Choice Factors }\end{array}$ & $\begin{array}{l}\text { External Neoclassical } \\
\text { Efficient Choice Factors }\end{array}$ \\
\hline $\begin{array}{l}\text { Internal motives stemming from within an } \\
\text { organisation, and based on organisational } \\
\text { performance, profitability and efficiency, in which } \\
\text { that organisation responds primarily to market and } \\
\text { regulatory incentives, and is led to implement } \\
\text { environmental initiatives }\end{array}$ & $\begin{array}{l}\text { External motives stemming from influences } \\
\text { operating from outside an organisation, and based on } \\
\text { organisational performance, profitability and efficiency, } \\
\text { in which the organisation responds primarily to market } \\
\text { and regulatory incentives and is led to implement } \\
\text { environmental initiatives }\end{array}$ \\
\hline $\begin{array}{l}\text { Internal Social } \\
\text { Institutional Factors }\end{array}$ & $\begin{array}{l}\text { External Social } \\
\text { Institutional Factors }\end{array}$ \\
\hline $\begin{array}{l}\text { Internal motives stemming from within an } \\
\text { organisation related to social and institutional } \\
\text { pressures which persuade an organisation to adopt } \\
\text { environmental practices }\end{array}$ & $\begin{array}{l}\text { External motives stemming from influences } \\
\text { operating from outside an organisation, related to } \\
\text { social and institutional pressures, persuading an } \\
\text { organisation to adopt environmental practices }\end{array}$ \\
\hline
\end{tabular}

Figure 2. Efficient choice-social institutional EMS classification model [14]

\section{METHODOLOGY}

Questionnaires were distributed across organisations in Nigeria $(n=350)$ between August and December 2012. As questionnaires were to be filled directly by respondents in organisations and the accuracy of responses could not be verified, the possibility of an inherent self-reporting bias existed $[29,20]$ reported on the possibility of respondent interpretation problems in studies where EMS motivations and outcomes are measured together, as EMS drivers could also be benefits for respondents. Reference [30] also identified the possibility of reverse causality bias, in which of EMS benefits might influence respondents' perception of its drivers. To reduce these biases and ensure that the questionnaire would be understood by respondents, questionnaire administration involved the following phases:

- Phase one: Questionnaire Pre-testing - A pre-testing of the survey questionnaires was conducted. Six (6) organisations, comprising 2 environmental certification bodies, 3 environmental management consultancies and 1 oil and gas upstream company, were asked to assess the draft survey questionnaire and provide feedback on its suitability and content by filling out a Questionnaire Pre-testing Form; 
- Phase two: Questionnaire Pilot Testing - The revised draft questionnaire was then pilot-tested by administering it to twenty-two (22) organisations. Administration was done via email and through direct delivery to each organisation's relevant contact persons. After intensive follow-up through email messages and telephone calls, a total of 15 responses were retrieved, representing a response rate of $68 \%$ in the pilot survey;

- Phase three: Final Questionnaire Administration - The final reviewed questionnaire was then administered to a total of 350 organisations. Questionnaires were administered via email, local post and direct delivery. Organisations in the following geographical regions of Nigeria were amongst the sample population:

- Lagos region $(\mathrm{n}=37)$;

- Northern region (North-East, North-West and North Central) $(\mathrm{n}=76)$;

- Southern region (South-East, South-West and South-South) $(\mathrm{n}=23)$.

Table 2. Relationship between EMS implementation factors

\begin{tabular}{|c|c|c|c|c|c|}
\hline \multirow{2}{*}{$\begin{array}{c}\text { Research study } \\
\text { Powell and } \\
\text { Dimaggio, } 1991\end{array}$} & \multicolumn{4}{|c|}{ EMS study categorizations } & \multirow[b]{3}{*}{$\begin{array}{c}\text { Environmental } \\
\text { opportunities }\end{array}$} \\
\hline & $\begin{array}{l}\text { Coercive } \\
\text { pressures }\end{array}$ & $\begin{array}{l}\text { Mimetic } \\
\text { pressures }\end{array}$ & $\begin{array}{l}\text { Regulatory } \\
\text { pressures }\end{array}$ & & \\
\hline Tomer, 1992 & $\begin{array}{c}\text { Market } \\
\text { incentives }\end{array}$ & $\begin{array}{c}\text { Social } \\
\text { influences }\end{array}$ & $\begin{array}{l}\text { Regulatory } \\
\text { influences }\end{array}$ & $\begin{array}{c}\text { Internal } \\
\text { organisational } \\
\text { capabilities }\end{array}$ & \\
\hline $\begin{array}{c}\text { Bansal and } \\
\text { Howard, } 1997\end{array}$ & $\begin{array}{l}\text { Market } \\
\text { drivers }\end{array}$ & Social drivers & $\begin{array}{l}\text { Regulatory } \\
\text { drivers }\end{array}$ & $\begin{array}{l}\text { Financial } \\
\text { drivers }\end{array}$ & \\
\hline $\begin{array}{l}\text { Bansal and Roth, } \\
2000\end{array}$ & $\begin{array}{l}\text { Competitive } \\
\text { motives }\end{array}$ & $\begin{array}{l}\text { Relational } \\
\text { motives }\end{array}$ & $\begin{array}{l}\text { Ethical } \\
\text { motives }\end{array}$ & & \\
\hline $\begin{array}{l}\text { Jiang and Bansal, } \\
2003\end{array}$ & $\begin{array}{l}\text { Market } \\
\text { demands }\end{array}$ & $\begin{array}{l}\text { Management } \\
\text { control }\end{array}$ & $\begin{array}{l}\text { Institutional } \\
\text { pressures }\end{array}$ & & \\
\hline $\begin{array}{c}\text { Matuszak-Flejsman, } \\
2008\end{array}$ & $\begin{array}{l}\text { Commercial } \\
\text { drivers }\end{array}$ & $\begin{array}{l}\text { Ethical } \\
\text { drivers }\end{array}$ & Legal drivers & $\begin{array}{l}\text { Economic } \\
\text { drivers }\end{array}$ & \\
\hline $\begin{array}{l}\text { Neumayer and } \\
\text { Perkins, } 2005\end{array}$ & $\begin{array}{l}\text { Internal } \\
\quad \text { (or } \\
\text { efficiency) } \\
\text { motives }\end{array}$ & $\begin{array}{l}\text { External (or } \\
\text { institutional } \\
\text { motives) }\end{array}$ & & & \\
\hline Darnall et al, 2008 & $\begin{array}{c}\text { Market } \\
\text { pressures }\end{array}$ & $\begin{array}{c}\text { Social } \\
\text { pressures }\end{array}$ & $\begin{array}{l}\text { Regulatory } \\
\text { pressures }\end{array}$ & & \\
\hline Heras et al, 2011 & $\begin{array}{c}\text { Motivations } \\
\text { of an } \\
\text { internal } \\
\text { nature }\end{array}$ & $\begin{array}{c}\text { Motivations } \\
\text { of an external } \\
\text { nature }\end{array}$ & & & \\
\hline $\begin{array}{l}\text { Heras and Landin, } \\
2010\end{array}$ & $\begin{array}{l}\text { External } \\
\text { drivers }\end{array}$ & $\begin{array}{l}\text { Internal } \\
\text { drivers }\end{array}$ & & & \\
\hline
\end{tabular}

Questionnaires were distributed using e-distribution, mass mailing, and direct delivery, whereby questionnaires were delivered to potential respondents and retrieved at a later date. Nine industry sectors were represented within the completed questionnaires received as shown in Figure 3. As at December 31, 2012, 136 responses had been obtained (including responses from Phases 2 and 3), representing a response rate of $38.8 \%$. 


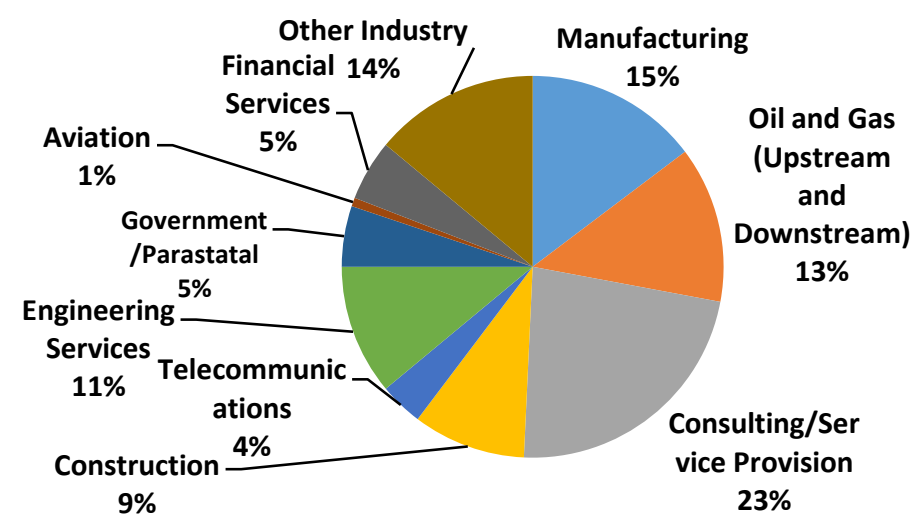

Figure 3. Proportion of questionnaire responses from each industry sector

\section{RESULTS}

\section{Percentage of organisations rating EMS drivers as 'Very Important' or 'Important'}

$87 \%$ of respondents considered 'environmental concern' as being 'very important' (VI) or 'important' (I) drivers influencing their pro-environmental behaviour (Figure 4). $87 \%$ also considered the 'desire for improved organisational efficiency' in the same way. 'Opportunity to avoid/contain pollution', 'regulatory/legal demands/pressures' and 'environmental/social responsibility' were rated by $85 \%, 84 \%$ and $83 \%$ of organisations respectively as being 'very important' or 'important' drivers.

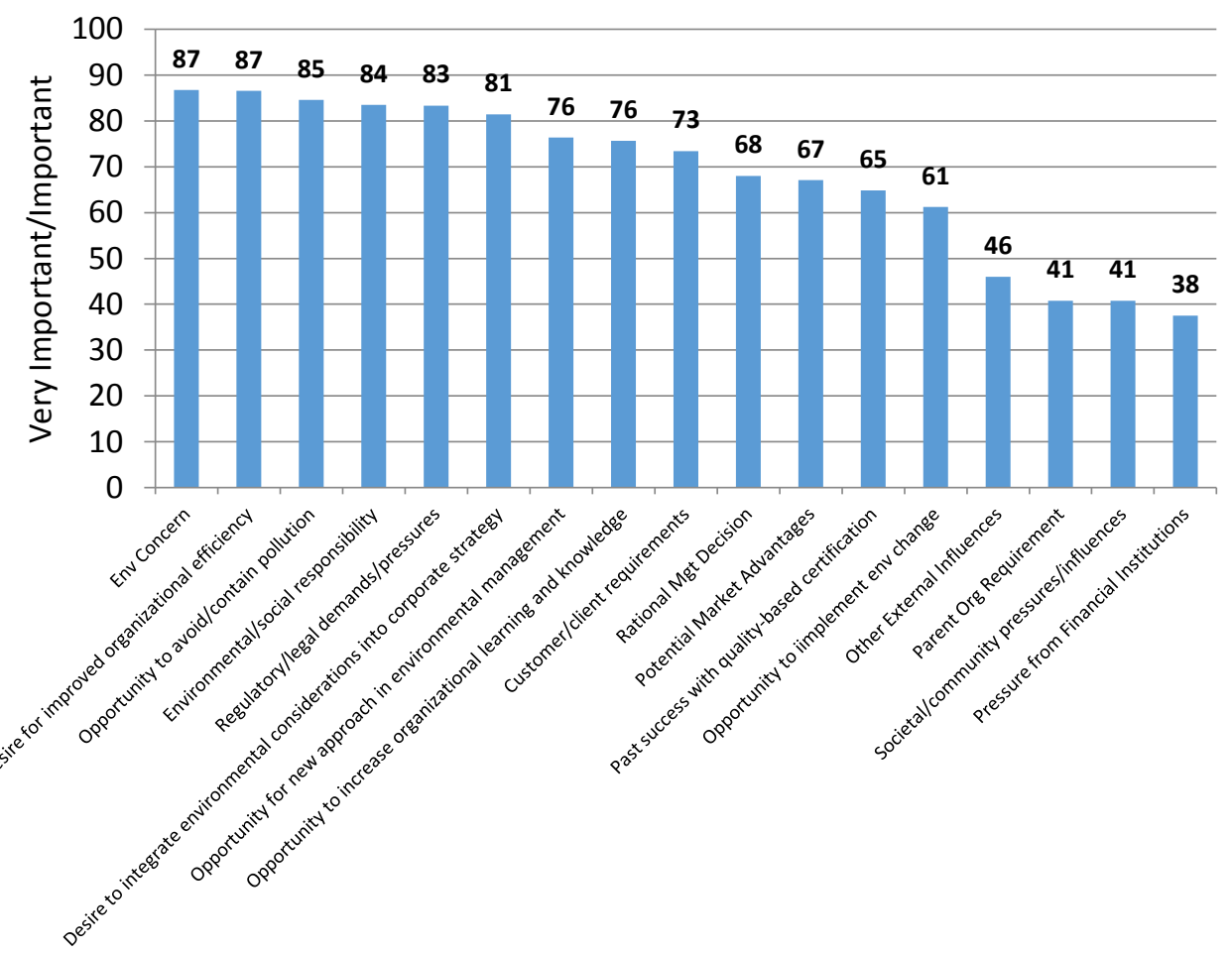

Figure 4. Organisations that rated EMS drivers as 'Very important' or 'Important'

\section{Percentage of organisations rating EMS benefits as 'Very Important' or 'Important'}

$90 \%$ of respondents considered 'reduced environmental accidents and site safety' as being a 'very important' or 'important' benefit influencing their pro-environmental behaviour (Figure 5). 'Enhanced corporate image', 'more efficient resource use', 
'improved employee knowledge and awareness of environmental issues' and 'improved external relations' were rated by $89 \%, 86 \%, 86 \%$ and $84 \%$ of organisations respectively as being 'very important' or 'important' benefits.
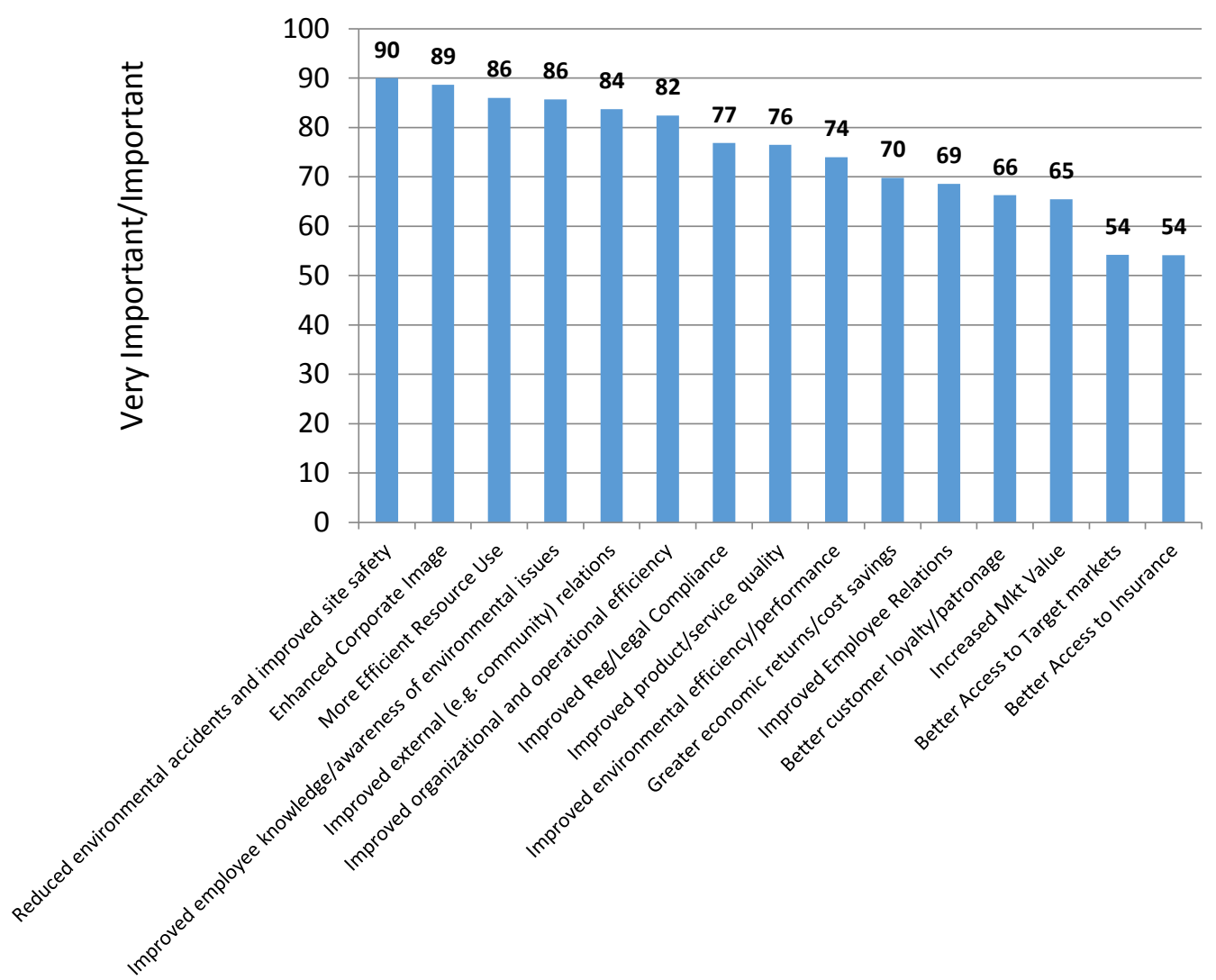

Figure 5. Organisations that rated EMS benefits as 'Very important' or 'Important'

\section{Percentage of organisations rating EMS barriers as 'Very Important' or 'Important'}

$70 \%$ of respondents considered the cost of implementation/budget barriers' as being a 'very important' or 'important' barrier influencing their pro-environmental behaviour (Figure 6). 'Lack of resources', 'regulatory agency bureaucracy' and 'extensive documentation involved' and 'lack of concern about environmental issues' were rated by $69 \%, 68 \%, 61 \%$ and $61 \%$ of organisations respectively as being 'very important' or 'important' barriers.

\section{Comparison of EMS implementation factors' ratings using FACES model}

EMS Implementation Factors (drivers, benefits and barriers) were grouped using the FACES model explained in [13] (in Figure 2 above), and respondents' combined ratings were compared. The y-axis in Figure 7 represents the percentage of organisations rating a driver as 'very important' or 'important'. The x-axis represents EMS implementation factors. The 'coverage area' is a function of the number of EMS implementation factors and the 'very important'/'important' (VI/I) ratings:

Coverage area in graph $=$ No. of EMS implementation factors $\times$ VI/I rating

The graph shows the blue line (representing all Internal Efficient Choice EMS Factors in the research questionnaire) having the overall highest coverage area. The green line 
(Internal Social Institutional EMS Factors) with the next highest, is followed by the red line (External Efficient Choice EMS Factors) and the purple line (External Social Institutional EMS Factors).

\section{DISCUSSION}

\section{EMS drivers in developed vs. developing countries}

From survey results on EMS implementation factors, it appears that both internal (efficient choice and social institutional) EMS factors have comparable influences on the pro-environmental behaviour of Nigerian organisations. A high proportion of respondents considered internal efficient choice EMS drivers like 'desire for improved organisational efficiency' $(87 \%)$ and 'opportunity to integrate environmental considerations into corporate strategy' $(81 \%)$ to be 'very important' or 'important'. Respondents also rated internal social institutional EMS drivers like 'environmental concern' (87\%), 'opportunity to avoid/contain pollution' (85\%) and 'environmental/social responsibility' $(84 \%)$ to be 'very important' or 'important'. This demonstrates that while motivated by efficiency and profitability, Nigerian organisations possess a degree of environmental awareness and concern.

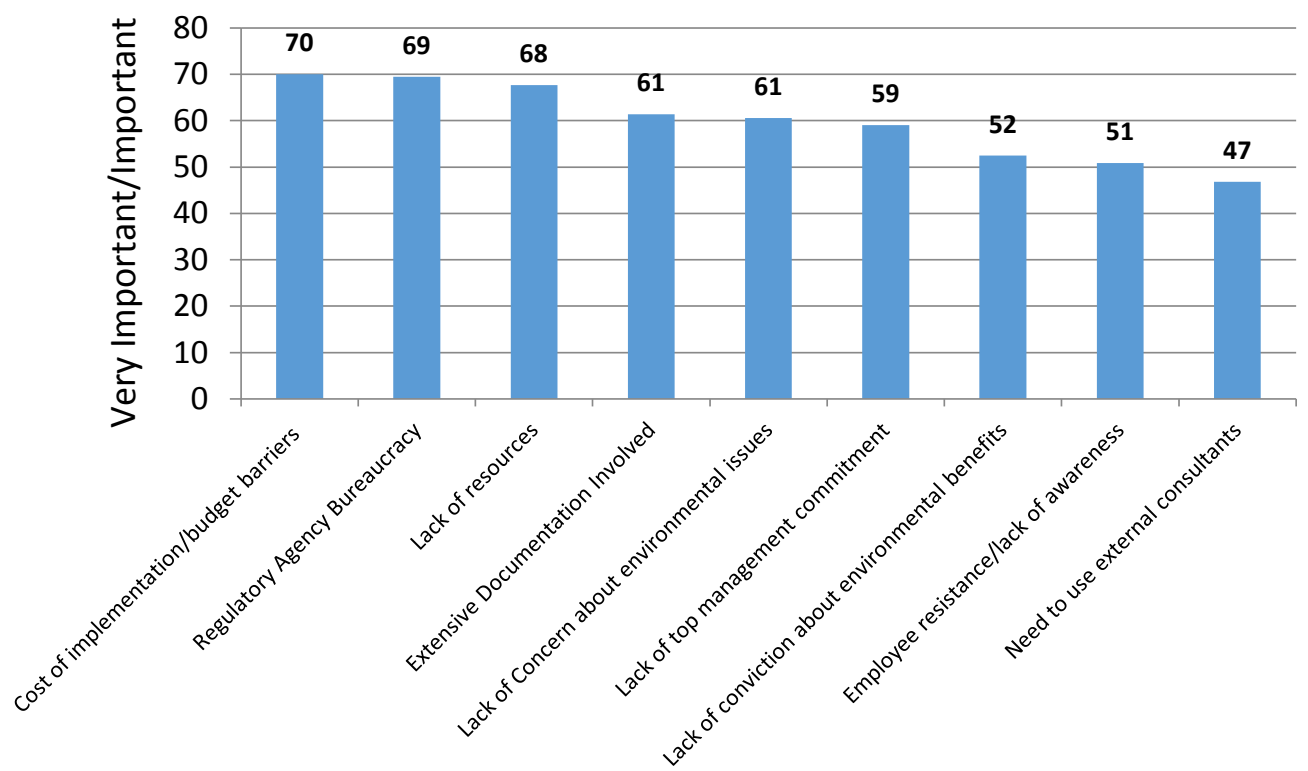

Figure 6. Organisations that rated EMS barriers as 'Very important' or 'Important'

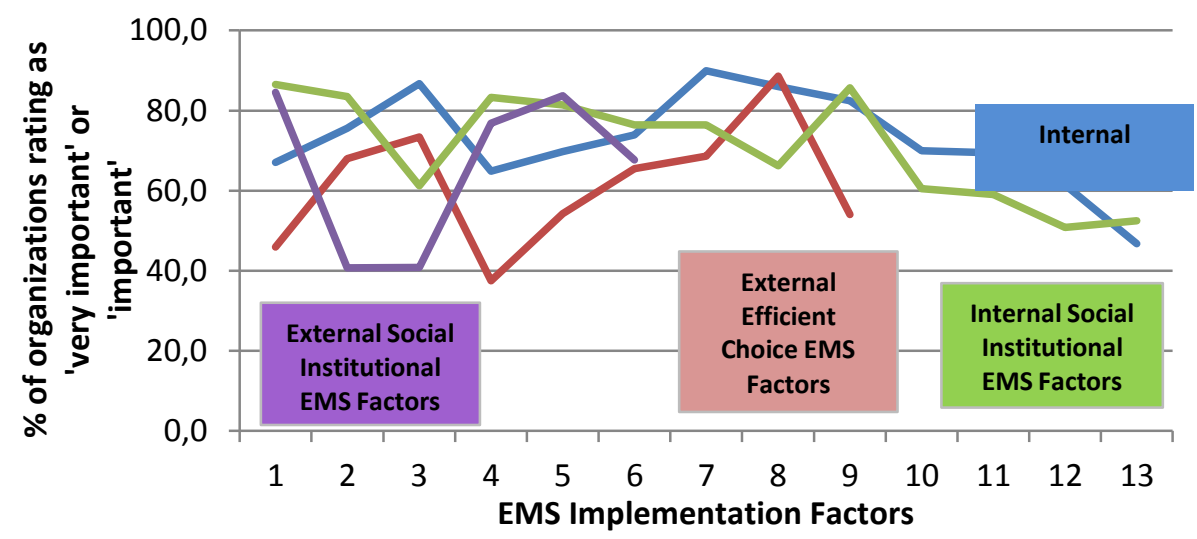

Figure 7. Comparison of ratings of EMS implementation factors 
Internal EMS factors appear to influence Nigerian organisations to a greater extent than external EMS factors; as external efficient choice EMS drivers like 'customer/client requirements' (73\%) and 'potential market advantages' $(67 \%)$ were not rated as highly as internal drivers. Empirical literature on EMS drivers reports contrasting results, with studies generally suggesting that EMS motivations are more of an external nature $[3,31$, 6]. In addition, a large number of studies assert that organisations' pro-environmental behaviour is influenced by the demands of their respective markets $[5,12,16,32]$. The conclusions of these studies are in contrast with survey results on Nigerian organisations. Customer requirements and market advantages do not appear to play a major role in motivating pro-environmental behaviour in Nigeria potentially because:

- They operate in markets where customers do not associate environmental performance with product quality;

- Market domination can be achieved without superior environmental performance;

- They do not supply international markets, where supplier environmental performance is considered important;

- Local markets are not as environmentally sensitive as their developed country counterparts.

The external EMS factor, 'regulatory/legal demands/pressures' (83\%) also exerts influence on Nigerian organisations. This result is in line with previous studies [8, 33, 34], which conclude that government-backed regulation is a strong driver of pro-environmental behaviour, and will continue to promote the adoption of EMS certification standards. Regulatory drivers are an influential driver for pro-environmental behaviour in developing countries like Nigeria, particularly because a failure to achieve regulatory compliance ultimately leads to unwanted outcomes like legal sanctions, fines, penalties and loss of operating licenses and permits. Organisations wishing to implement environmental initiatives become immediately aware of the existence of legal requirements, and their responsibility to operate within them.

Respondents responses also indicated that a lower proportion of Nigerian organisations are influenced by external social institutional EMS factors like 'societal/community influences' (41\%) and 'other external influences' (46\%) such as trade associations, lobbyists, consultants and educational institutions. This may be due to a level of environmental awareness in these external parties insufficient to influence pro-environmental behaviour.

\section{EMS benefits in developed vs. developing countries}

External efficient choice benefits such as 'better customer loyalty/patronage' (66\%), 'increased market value' (65\%), and 'better access to target markets' (54\%), were not rated as highly as internal EMS factors. This demonstrates that Nigerian organisations derive fewer market benefits from pro-environmental behaviour than their developed country counterparts. This may be because Nigerian markets are not environmentally conscious or sensitive enough to demand environmental performance.

The link between market benefits and pro-environmental behaviour has been emphasized by studies such [18, 35, 36]. These studies suggest that:

- An organisations environmental performance may be a barrier to exporting products to international markets;

- The existence of ems certifications facilitates product export to developed country markets, and is useful in overcoming difficult international trade barriers;

- Those organisations may lose competitive position in local and international markets by failing to pay sufficient attention to environmental issues. 
However, though it appears that Nigerian organisations do not gain as many market/trade benefits as they do internal benefits, the degree to which Nigerian markets are environmentally sensitive has not been determined. Market access-driven advantages provided by EMS implementation may be based on perceived rather than actual realities. As such, the extent of environmental sensitivity in developing country markets like Nigeria presents an opportunity for future research.

Survey results showing a positive relationship between pro-environmental behaviour and employee relationships in Nigerian organisations are in agreement with those of previous studies, which report the positive, though often difficult to measure, effect of environmental initiatives on organisation's employee relationships [8, 15, 16, 32, 36-38].

$84 \%$ of respondents rated 'improved external (community) relations' as being a 'very important' or 'important EMS benefit. However, only $41 \%$ of respondents considered 'societal/community pressures/influences' as 'very important' or 'important' EMS driver. This demonstrates that although Nigerian organisations are not primarily motivated by their external communities, they derive community benefits from pro-environmental actions. This indicates that Nigerian communities may not be as environmentally insensitive as they appear.

\section{EMS barriers in developed vs. developing countries}

The highest rated EMS barriers were 'cost of implementation/budget barriers' (70\%), 'lack of resources' (69\%), 'regulatory agency bureaucracy' $(68 \%)$ and 'extensive documentation involved' (61\%). The cost outlay of pro-environmental initiatives is substantial, and many organisations (including those in Nigeria) are cautious about incurring expenses that do not have a perceived direct link to organisational bottom-line [8, 16, 34, 38]. Moreover, a barrier to pro-environmental behaviour in Nigerian organisations is the challenge of dealing with environmental regulatory bodies. According to [25] and [39], there is a general lack of cooperation between Federal and State environmental protection bodies in Nigeria, leading to bureaucratic delays. Regulatory bureaucracy is also caused by the existence of multiple overlapping functions within environmental protection bodies subsequently leading to overlapping mandates, functions, jurisdictions and permitting systems.

\section{CONCLUSION}

Nigerian organisations are more motivated towards pro-environmental behaviour by internal (efficient choice and social institutional) EMS factors than by external EMS factors. They also derive fewer market benefits from pro-environmental behaviour than their developed country counterparts, potentially because of a reduced environmental consciousness or sensitivity. Similar to organisations in developed and emerging economies, Nigerian organisations are hindered from exhibiting pro-environmental behaviour by internal efficient choice barriers such as the cost of EMS implementation, budget barriers, a lack of resources and the extensive documentation involved. External EMS factors such as regulatory agency bureaucracy as are strong driver of pro-environmental behaviour.

Resource constraints and the high cost of cross-country travel for direct administration restricted the size of the sample population. Future opportunities exist for conducting research on EMS implementation aspects in Nigeria and other developing countries in:

- Investigating trends or causal relationships between different organisational characteristics (such as organisation size as a function of the number of employees, industry sector, geographical location, organisation turnover, 
organisations ownership structure and organisation corporate structure) of organisations in developing countries and how EMS drivers, benefits and barriers are perceived;

- Investigating trends or causal relationships between organisational characteristics and developing countries organisations' level of environmental management;

- Comparing how organisations rate 'non-EMS' benefits (e.g. Better customer loyalty) derived from EMS implementation against EMS benefits (e.g. Reduced environmental incidents.

\section{ACKNOWLEDGEMENT}

This research work was partly supported by the Petroleum Technology Development Fund (PTDF), Nigeria.

\section{REFERENCES}

1. Bansal, P., Bogner, W., Deciding on ISO 14001: Economics, Institutions and Context, Long Range Planning, 35, pp 269-290, 2002, http://dx.doi.org/10.1016/S0024-6301(02)00046-8

2. Delmas, M., The Diffusion of Environmental Management Standards in Europe and the United States: An Institutional Perspective, Policy Sciences, Vol. 35, pp 91-119, 2002, http://dx.doi.org/10.1023/A:1016108804453

3. Zutshi, A., Sohal, A., Environmental Management System adoption by Australasian organisations: Part 1 Reasons, benefits and impediments, Technovation, Vol. 24, pp 335-357, 2004, http://dx.doi.org/10.1016/S0166-4972(02)00053-6

4. Kehbila, A. G., Ertel, J., Brent, A. C., Strategic Corporate Environmental Management within the South African Automotive Industry: Motivations, Benefits, Hurdles, Corporate Social Responsibility and Environmental Management, Vol. 16, No.6, pp 310-323, 2009, http://dx.doi.org/10.1002/csr.188

5. Nawrocka, D., Parker, T., Finding the Connection: Environmental Management Systems and Environmental Performance, Journal of Cleaner Production, Vol. 17, pp 601-607, 2009, http://dx.doi.org/10.1016/j.jclepro.2008.10.003

6. Heras, I., Landin, A. G., Alternative Models for Environmental Management in SME's: The Case of Ekoscan vs. ISO 14001, Journal of Cleaner Production, Vol. 18, pp 726-735, 2010, http://dx.doi.org/10.1016/j.jclepro.2010.01.005

7. Massoud, M., Fayad, R., El-Fadel, M., Kamleh, R., Drivers, Barriers and Incentives to Implementing Environmental Management Systems in the Food Industry: A Case of Lebanon, Journal of Cleaner Production, Vol. 18, pp 200-209, 2010, http://dx.doi.org/10.1016/j.jclepro.2009.09.022

8. Zorpas, A., Environmental Management Systems as Sustainable Tools in the Way of Life for the SME's and VSME's, Bioresource Technology, Vol. 101, pp 1544-1557, 2010, http://dx.doi.org/10.1016/j.biortech.2009.10.022

9. Boiral, O., Managing with ISO Systems: Lessons for practice, Long Range Planning, Vol. 44, pp 197-220, 2011, http://dx.doi.org/10.1016/j.Irp.2010.12.003

10. Hertin, J., Berkhout, F., Wagner, M., Tyteca, D., Are EMS Environmentally Effective? The Link between Environmental Management Systems and Environmental Performance in European Companies, Journal of Environmental Planning and Management, Vol. 51, No. 2, pp 259-283, 2008, http://dx.doi.org/10.1080/09640560701865040

11. Jabbour, C., da Silva, E., Paiva, E., Santos, F., Environmental Management in Brazil: Is it a Completely Competitive Priority?, Journal of Cleaner Production, Vol. 21, pp 11-22, 2012, http://dx.doi.org/10.1016/j.jclepro.2011.09.003 
12. Darnall, N., Henriques, I., Sadorsky, P., Do Environmental Management Systems improve Business Performance in an International Setting?, Journal of International Management, Vol. 1, No. 4, pp 364-376, 2008, http://dx.doi.org/10.1016/j.intman.2007.09.006

13. Kola-Lawal, C., Wood, M., Alo, B., Clark, A., (in prep), A Consolidated Categorization Model for Environmental Management System Implementation Factors (Drivers, Benefits and Barriers)

14. ISO, (2008), The ISO Survey 2008, http://www.iso.org/iso/iso-survey2008.pdf, [Accessed: 11-Jan-2012]

15. Gavronski, I., Ferrer, G., Paiva, E., ISO 14001 Certification in Brazil: Motivations and Benefits, Journal of Cleaner Production, Vol. 16, pp 87-94, 2008, http://dx.doi.org/10.1016/j.jclepro.2006.11.002

16. Jiang, R., Bansal, P., Seeing the Need for ISO 14001, Journal of Management Studies, Vol. 40, pp 1047-1067, 2003, http://dx.doi.org/10.1111/1467-6486.00370

17. Bellesi, F., Lehrer, D., Tal, A., Comparative Advantage: The Impact of ISO 14001 Environmental Certification on Exports, Environmental Science \& Technology, Vol. 39, No. 7, pp 1943-1953, 2005, http://dx.doi.org/10.1021/es0497983

18. Cahsore, B., van Kooten, G., Vertinsky, I., Auld, G., Affolderbach, J., A Comparative Study of Forest Certification Choices in Canada, the US and Germany, Forest and Policy Economics, Vol. 7, pp 53-69, 2005, http://dx.doi.org/10.1016/S1389-9341(03)00011-X

19. Heras-Saizarbitoria, I., Arana Landin, G., Francisco Molina-Azorin, J., Do Drivers Matter for the Benefits of ISO 14001?, International Journal of Operations \& Production Management, Vol. 31, No. 1-2, pp 192-21, 2011, http://dx.doi.org/10.1108/01443571111104764

20. Curkovic, S., Sroufe, R., Using ISO 14001 to Promote a Sustainable Supply Chain Strategy, Business Strategy and the Environment, Vol. 20, No. 2, pp 71-93, 2011.

21. Radonjic, G., Tominc, P., The Role of Environmental Management System on Introduction of New Technologies in the Metal and Chemical/paper/plastics Industries, Journal of Cleaner Production, Vol. 15, pp 1482-1493, 2007, http://dx.doi.org/10.1016/j.jclepro.2006.03.010

22. Gonzalez, P., Sarkis, J., Adenso-Diaz, B., Environmental Management System Certification and its Influence on Corporate Practices - Evidence from the Automotive Industry, International Journal of Operations \& Production Management, Vol. 28, No. 11-12, pp 1021-1041, 2008, http://dx.doi.org/10.1108/01443570810910179

23. Comoglio, C., Botta, S., The use of Indicators and the Role of Environmental Management Systems for Environmental Performances Improvement: A Survey on ISO 14001 Certified Companies in the Automotive Sector, Journal of Cleaner Production, Vol. 20, No. 1, pp 92-102, 2011, http://dx.doi.org/10.1016/j.jclepro.2011.08.022

24. Chan, E. S. W., Hawkins, R., Attitude towards EMSs in an International Hotel: An Exploratory Case Study, International Journal of Hospitality Management, Vol. 29, No. 4, pp 641-651, 2010, http://dx.doi.org/10.1016/j.ijhm.2009.12.002

25. Eneh, O. C., Managing Nigeria's Environment: The Unresolved Issues, Journal of Environmental Science and Technology, Vol. 4, No. 3, pp 250-263, 2011, http://dx.doi.org/10.3923/jest.2011.250.263

26. Tomer, J., The Human Firm in the Natural Environment: A Socio-economic Analysis of its Behavior, Ecological Economics, Vol. 7, pp 119-138, 1992, http://dx.doi.org/10.1016/0921-8009(92)90009-H

27. Melnyk, S. A., Sroufe, R. P., Calantone, R. L., Montabon, F. L., Assessing the Effectiveness of US Voluntary Environmental Programmes: An Empirical Study, 
International Journal of Production Research, Vol. 40, No. 8, pp 1853-1878, http://dx.doi.org/10.1080/00207540110118398

28. Henri, J. F., Journeault, M., Environmental Performance Indicators: An Empirical Study of Canadian Manufacturing Firms, Journal of Environmental Management, Vol. 87, No. 1, pp 165-176, http://dx.doi.org/10.1016/j.jenvman.2007.01.009

29. Casadesus, M., Marimon, F., Heras, I., ISO 14001 Diffusion after the Success of the ISO 9001 Model, Journal of Cleaner Production, Vol. 16, No. 16, pp 1741-1754, 2008, http://dx.doi.org/10.1016/j.jclepro.2007.11.002

30. Boiral, O., \& Roy, M., ISO 9000: Integration Rationales and Organisational Impacts, International Journal of Operations Management, Vol. 27, No. 2, pp 226-247, 2007, http://dx.doi.org/10.1108/01443570710720630

31. Gonzalez-Benito, J., Gonzalez-Benito, O., Operations Management Practices linked to the Adoption of ISO 14001: An Empirical Analysis of Spanish Manufacturers, International Journal of Production Economics, Vol. 113, No. 1, pp 60-73, 2008, http://dx.doi.org/10.1016/j.ijpe.2007.02.051

32. Sambasivan, M., Fei, N., Evaluation of Critical Success Factors of Implementation of ISO 14001 using Analytic Hierarchy Process (AHP): A Case Study from Malaysia, Journal of Cleaner Production, Vol. 16, pp 1424-1433, 2008, http://dx.doi.org/10.1016/j.jclepro.2007.08.003

33. Matsuzak-Flejsman, A., Benefits of Environmental Management Systems in Polish Companies Compliant with ISO 14001, Polish Journal of Environmental Studies, Vol. 18, No. 3, pp 411-419, 2009.

34. Curkovic, S., Sroufe, R., Melnyk, S., Identifying the Factors which Affect the Decision to attain ISO 14000, Energy, Vol. 30, No. 8, pp 1387-1407, 2005, http://dx.doi.org/10.1016/j.energy.2004.02.016

35. Quazi, H., Khoo, Y., Tan, C., Wong, P., Motivation for ISO 14001 Certification: development of a Predictive Model, Omega, Vol. 29, pp 525-542, 2001, http://dx.doi.org/10.1016/S0305-0483(01)00042-1

36. Oliveira, O., Serra, J., Salgado, M., Does ISO 14000 work in Brazil?, Journal of Cleaner Production, Vol. 18, pp 1797-1806, 2010, http://dx.doi.org/10.1016/j.jclepro.2010.08.004

37. Link, S., Naveh, E., Standardization and Discretion: Does the Environmental Standard ISO 14001 Lead to Performance Benefits, IEEE Transactions on Engineering Management, Vol. 53, No. 4, pp 508-519, 2006, http://dx.doi.org/10.1109/TEM.2006.883704

38. Chan, E. S. W., Hawkins, R., Attitude towards EMSs in an International Hotel: An Exploratory Case Study, International Journal of Hospitality Management, Vol. 29, No. 4, pp 641-651, 2010, http://dx.doi.org/10.1016/j.ijhm.2009.12.002

39. Allen, F., Implementation of Oil-related Environmental Policy in Nigeria: Government Inertia and Conflict in the Niger Deltam, PhD Thesis, University of Kawzulu-Natal, South Africa, 2011. 